UNIVERSITY OF CALIFORNIA

COLLEGE OF AGRICULTURE

BERKELEY
AGRICULTURAL EXPERIMENT STATION

BENJ. IDE WHEELER, PRESIDENT

THOMAS FORSYTH HUNT, DEANAND. DIRECTON

H. E. VAN NORMAN, VICE-DIRECTOR AND DEAN

CIRCULAR No. 189

JANUARY, 1918

\title{
WINTER FORAGE CROPS
}

\author{
BY P. B. KENNEDY
}

The erops that may be grown in this state during the winter season for forage purposes are:

Canada field peas

Common vetch

Sand or hairy veteh

Horse beans

Rape

Kale

Giant marrow cabbage

White mustard

Root erops
Bur-clover

Sweet clover

Italian rye grass

English rye grass

Orchard grass

Crested dog's-tail grass

Tall meadow oat grass

Rye

Barley

FIELD PEAS

Field peas are adapted to moderate temperatures and will withstand frost, but not severe freezing weather. They will also grow at high altitudes. Where the winters are cold they must be sown in spring under irrigation or on land that has previously been prepared so as to conserve the moisture. On the coast and in the interior valleys, fall sowing on well-drained land is recommended. The crop may be grown for hay, soiling, silage, pasture or seed. It is palatable to all classes of stock in any of its forms.

The soil should contain an abundance of lime and where this is not present naturally, 1000 to 2000 pounds of burned lime or double this quantity of ground limestone per acre should be applied.

There are about 100 varieties of field peas, differing in earliness, amount of herbage and the size and color of the flowers and pods. The seeds of some varieties are round and smooth while others are wrinkled and angular. In color they vary from light yellow to green, brown, black or speckled. Some of the best varieties are Colorado White, Black-eye Marrowfat, Arthur, Golden Vine, Prussian Blue. The weight of a bushel of peas varies from fifty-two to sixtyeight pounds, depending upon the variety and the quality of the seed. The seed will germinate well, even when several years old. In some 
regions the pea-weevil is a serious pest. The larva eats out a hole in the seed, reducing its food value and interfering with germination. To destroy the weevil, place the seeds in an air-tight receptacle (garbage can will do for small amounts) and treat with carbon bisulphide. Allow about three pounds of the bisulphide for 1000 cubic feet of space. Place the liquid in pans on the top of the seed and it will volatilize, the gas penetrating downward as it is heavier than air. Leave for about twenty-four hours and spread the seed out or admit plenty of fresh air. Be careful with fire.

Field peas may be broadcasted or drilled alone, or sown with a cereal crop, preferably oats or rye. Drilling insures more even and certain germination. On heavy soils sow to a depth of from two inches to as much as four inches on the lighter soils. A disk drill having a revolving cup type of feed is to be preferred as less of the seed is crushed. Stop up the holes so as to plant in double rows, sixteen inches apart. Where cultivation is necessary for the conservation of moisture the rows should be placed at a greater distance. Fair success can be obtained by broadcasting on fallowed land or on land that has been previously in a hoed crop and disking or plowingunder the seed lightly. The rate of seeding varies according to the method and locality where the crop is to be grown and whether it is to be sown alone or with a cereal. If alone, one and a half bushels is required for the small-seeded varieties to three bushels for the large-seeded ones. In humid regious one bushel of peas and two bushels of oats is the most satisfactory for the production of hay, while in dry regions two bushels of peas and one of oats have proved the most successful. For seed purposes the amount should be considerably less, namely, one bushel of peas to twenty pounds of oats which are mixed before seeding.

The best time to cut for hay is when the plants have the first pods well grown but not matured and the vines still blossoming. This will result in the largest amount of protein and the highest yield. When grown for hay it is nearly always advantageous to sow the peas with oats or rye. This has a tendency to maintain the vines erect and will make mowing and curing easier. A distinct advantage is to have an attachment to the mower known as a pea harvester which consists of guards which lift up the peas and permits the cutter bar free passage. It costs from $\$ 12$ to $\$ 15$. Ten tons or more of green fodder or about three tons of hay per acre may be expected on good land. Sheep, particularly lambs, will increase in weight rapidly if allowed to pasture the crop when mature. A good crop of peas will fatten from ten to fifteen lambs per acre, the lambs gaining about 
eight pounds per month. From seventy to ninety days will place them in excellent market condition. On small farms movable fences are a distinct advantage and reduce waste in feeding. The crop may also be "hogged off" in a similar manner and an excellent quality of bacon produced. Wherever corn is desirable in the animal economy, peas will be found an excellent substitute. Silage may also be made from the green vines by stacking them or putting them into the silo. It may be fed all classes of stock. The mature crop should be harvested before the seed is hard in the pod to lessen the loss from shattering. The seed may be flailed or thrashed with an ordinary grain thrasher, or by a pea huller, of which there are several on the market. Trampling the seed out with horșes or passing a concrete roller back and forward over the vines has also proved satisfactory. One ton of seed per acre would be considered a good yield. The straw has considerable food value and will be readily eaten by stock, particularly sheep. It should never be burned, as it will add considerable humus to the soil if plowed under. A ton to a ton and a half of straw per acre may be expected.

\section{COMMON VETCH}

Common vetch is adapted to the same general conditions of soil and climate as the field pea. In different parts of the country it is known by the following names: Smooth vetch, English vetch, Oregon winter vetch, spring vetch and tares. It will grow on a variety of soils but seems to be best adapted to well-drained rich sandy or gravelly loams. Unlike most other legumes its lime requirement is low. The seed bed should be well prepared but left firm. Go over the land with a roller or subsurface packer so as to firm the soil and then harrow again very lightly. Gypsum at the rate of 100 pounds per acre has been found to increase the yields of hay on some soils. Fall planting is the general rule on the coast and valley sections where the winter temperature keeps above $15^{\circ} \mathrm{F}$. Where the summers are hot and dry it is useless to sow in the spring.

Lack of inoculation may cause the crop to be a failure. In remote districts or new regions where vetch has not been well established it would be advisable to provide inoculation. Secure about five hundred pounds of soil for each acre to be planted, from an old field in which vetch has been successfully grown. Spread the soil evenly over the surface, preferably on a cloudy day and have someone follow with the harrow immediately as the legume bacteria are destroyed by exposure to bright sunshine. For various reasons this method cannot always be carried out. Reluctance on the part of the farmer 
to have his fields disturbed, the labor of hauling and the replacing of the soil taken away are the chief hindrances. Where vetch is to be grown extensively it is advisable to sow a small area first on good well-manured land, treating the seed with one or another of the commercial cultures now on the market and using the soil from this area for larger plantings.

The rate of seeding varies considerably. Where there is apt to be danger from winter killing, heavy seeding is desirable. One hundred and twenty pounds per acre under poor conditions of soil and climate to as low as sixty pounds per acre under favorable conditions are necessary. The same holds true when sown with oats, a heavy seeding being ninety pounds of vetch and seventy pounds of oats. As low as forty pounds of vetch and ten pounds of oats have produced good crops. The present price of common vetch seed is about five cents per pound. Seed one year old will probably germinate better than fresh seed and little difference is noted up to three years, when it rapidly deteriorates. In many coast sections vetch that has proved a failure the first year has produced large vields the second year. Thousands of acres in California now producing a scanty weedy pasture or a poor crop of oats could be sown to vetch or vetch and oats, with the result that there would be more and better feed for stock and the soil greatly benefited. Dairy farmers not growing alfalfa should utilize their farm manure for growing large crops of vetch:

The seed may be drilled or broadcasted in a similar manner to that described for field peas. The crop may be used as pasture, cut and fed green daily, put into the silo, or made into hay. Stock eat vetch with relish. Vetch should be pastured only when the land is dry, as otherwise much of the feed is destroyed by trampling and the soil unduly packed. As in the case of peas, the vines should be cut when the first blossoms have formed pods and the new growth still well in bloom. An ordinary mower may be used, with two men following the mower to fork it out of the way of the next swath. It is more satisfactory, however, to use a swather attachment which takes the place of the men. The hay should remain for at least a day before being bunched and shocked, but care must be taken that the leaves do not get too dry. From two to four tons of hay may be expected. A fair pasturage is produced at the base of the stems after soiling. By sowing at different dates, from October to February, a succession of green feed may be secured. Because of the palatability of the vetch hay and its high protein content, averaging 15 per cent, 
it is highly prized as a dairy feed. Steers being fed vetch may be expected to gain from two to three pounds daily.

\section{SAND OR HAIRY VETCH}

The hairy vetch is more drouth- and cold-resistant than the common vetch and may be sown in early fall in cold regions where irrigation is practiced. The young plants should be well established before winter sets in or they will winter-kill badly. On well-prepared ground where the moisture has been conserved it may be sown in the spring. Because of its drouth-resistant qualities it is better adapted to poor gravelly or sandy soils than the common vetch. It is much more tolerant of heat than the common vetch and makes its most rapid growth during warm spring weather.

The methods of seeding prescribed for common vetch may also be applied to the hairy vetch. As the seed is about one-half the size of the common vetch, much less is required per acre, twenty to thirty pounds being sufficient. The forage is relished by all classes of stock. The leafage remains green during the coldest weather of Lassen and Modoc counties and we have grown it in Nevada, where the thermometer reached ten degrees below zero and yet only the tender tips of the vines were frozen. One drawback is the cost of the seed, being usually three or more times that of the common vetch. As most of the seed came from Europe it is difficult to secure it in this country now at a reasonable price. Seed could, however, readily be grown in California and would be a profitable crop at the present time.

\section{HORSE BEANS}

The horse-bean plant is a tall coarse erect-stemmed vetch. The large-seeded flat varieties are preferred for human food and the smaller, more oval-seeded varieties for stock. The seed may be sown broadcast, alone, or with peas or vetch, or drilled in rows eight to fourteen inches apart. About four bushels of seed per acre are required. Fall planting is desirable as the plants dislike hot weather and under such conditions readily succumb to aphis or turn black. The best method of utilizing the leafage is by soiling, cutting the plants when in full bloom. If left for seed it should be cut when the lower pods turn black and put into shocks for about two weeks before threshing. Horses are very fond of the beans which are especially valuable to mix with oats in the feed ration where hard work is required.

\section{RAPE}

There are a number of kinds of plants known as rape. One called summer rape or colza is grown chiefly for the oil which is extracted 
by pressure from the seed, and the residuum, the rape-seed cake of commerce, used as concentrates. Another kind is called winter rape or cole seed and produces large leaves which make succulent forage. One of the best forage varieties is the Dwarf Essex which is well adapted to cool moist climates and loamy soils, rich in humus, although it will grow in any ordinary cultivated soils that are well drained. Where the winters are severe it must be sown in the spring, but on the coast and in the interior valleys winter sowing is more satisfactory. It will withstand about six degrees of frost without injury when established, but the young growth is more tender. Even if the tops are frozen the roots survive and send up new shoots and produce a crop. The land should be plowed deep and a thorough seed bed prepared. As the yield depends upon the fertility of the soil, the application of from ten to twenty tons of decomposed farm manure will bring good returns. The manure is spread evenly over the surface, disked into the surface soil thoroughly and then plowed under. Another method where the crop is to be grown in rows is to use a double mold-board plow and ridge up the land twenty-four inches apart. The manure is then placed in the bottom of the furrows, the ridges split and new ridges formed directly over the manure. Where the land has been cropped to beans, sorghums, potatoes, or similar crop and is already in fair tilth, the land could be ridged without a preliminary plowing. The ridge method will be a saving in manure and provide ample drainage. If the soils are light and apt to dry out it would be best not to ridge the land.

Three methods of seeding may be used, namely; cultivated rows, in close drills, or broadcasted. The first requires two pounds of good seed per acre with the rows twenty-four inches apart, the second four pounds and the third, five pounds. A grain drill may be used. The seed should not be covered more than one-half inch. Where conservation of moisture is necessary cultivated rows are to be preferred.

Rape is commonly utilized by pasturing to sheep and hogs. Cattle are apt to be wasteful as they destroy much of it by trampling, especially when broadcasted or close-drilled. It may also be used as a soiling crop and occasionally it has been put in the silo with success. Like a number of other forage plants care should be taken to avoid bloating. In order to prevent excessive purging salt should be supplied freely. Animals will do better on rape if they have access to some dry feed as straw, or stubble pasture. When used as a soiling crop for milch cows it should be fed just after milking, as it will otherwise taint the milk. The average yield of rape is about ten tons of green forage per acre. Under very favorable conditions, thirty 
tons have been obtained. It is ready to pasture from two to three months after seeding. An acre of rape will carry approximately fifteen sheep or hogs for one month. In regard to its feeding value it contains about 87 per cent water, 2 per cent ash, 8 per cent digestible carbohydrates and fat (fat formers) and 3 per cent digestible protein (flesh formers).

\section{KALE}

Kale is similar to rape in its requirements. The variety Thousand Headed is best for forage. It grows to a height of from three to five feet and produces heavy and continuous succulent feed. With irrigation it may be planted in early fall and will produce abundant feed during the winter and following summer. Without irrigation the land should be fallowed to conserve the moisture and the seed planted with the first rains, in hills about three feet apart each way. A few seeds are put in each hill and the young plants thinned out when they appear above ground. By this method cross- and lengthwise cultivation is possible and the moisture conserved throughout the summer.

Cattle will eat the leaves and sheep the leaves and stalks so that there is no waste. So far as known it is the only forage plant that can be utilized for greed feed both summer and winter without irrigation in California. For this reason it is prized by poultrymen.

\section{GIANT MARROW CABBAGE}

Giant marrow cabbage comes from the Island of Jersey and is said to be a hybrid secured by crossing kohl-rabi, thousand-headed kale and the Jersey chou. It is similar to kale except that the stems become very tall, thick and fleshy. The crop has given excellent results in Western Washington and may do well in the north coastal region of this state.

\section{MUSTARD}

White mustard may be sown broadcast in January or February on the poorer soils and furnish fair sheep feed in April or May. It may be grown in the interior valleys or coastal region and with or without irrigation.

\section{ROOT CROPS}

Roots are well adapted to the humid belt along the Pacific Coast without irrigation. They require clean land of good deep tilth. The land may be prepared in a similar manner to that described for rape. Seaweed is abundant on the coast and directly adjacent to many farms on which roots could be grown successfully. Where farm 
manure is not available seaweed may be plowed under by placing it in the furrows as the plow makes its rounds. Carrots and parsnips prefer the lighter soils, and mangels, turnips, swedes and rutabagas, the heavier soils.

About four pounds of seed per acre are required except mangels, of which about twelve pounds are required. Sow in rows so as to cultivate and thin out to from six to two feet according to size of roots.

Mangels are related to the sugar beet and should be selected for growth in the south and interior valleys as they are more tolerant of heat.

From ten to twenty-five tons per acre or more may be expected according to the fertility of the land and the kind of crop grown. To be sure root crops are mostly water, so that if their chemical composition alone is to be considered little could be expected. For centuries, however, it has been known that the adding of a succulent easily digestible food to the ration is both healthful and economical.

The dry matter of all root crops is of the same general feed value, but different kinds of root crops differ greatly in the amounts of dry matter and water that they contain. A pound of dry matter in mangels and other root crops is equivalent to about one pound of grain and mangels can be substituted for about one-half of the necessary grain ration in the proportion of about twelve to fifteen pounds of mangels per pound of grain. Root crops may be fed to milch cows, sheep or steers with good results. They will prove a valuable factor in increasing the flow of milk where cows have access only to dry hay or dry pasture. A steer being fattened on dry feed will make better use of the ration when some roots are included. Their value for fattening lambs and maintaining a supply of milk in breeding ewes is well known.

\section{SWEET CLOVER}

Sweet clover has been grown to-a considerable extent in the eastern and middle western states for a number of years. Only recently, however, has its merits as a forage crop been recognized in California. Two factors have militated against it, namely, its bitter taste which makes stock dislike it until accustomed to it, and the uncertainty of securing a stand.

There have been many failures with sweet clover, mostly due to one of the following causes:

1. Lack of lime in the soil.

2. Lack of inoculation.

3. The loose character of the seed bed. 
The physical texture of the soil seems to be of little consequence as bountiful crops have been grown on very light sandy soils and on stiff adobe lands. Its tolerance for white alkali is well marked. When well established the roots withstand extremes of both heat and cold. Young seedlings are injured if a period of dry cold weather follows soon after germination, although a sufficient number of plants will usually survive to produce a good stand.

Sweet clover is extremely drouth-resistant on good deep wellprepared lands, maintaining bright green foliage to a height of several feet throughout the hottest months of the year. On poor shallow soils the growth is sometimes sparse and many of the leaves turn brown and fall off. Gravelly stream beds and banks seem to be its natural preference and we find it taking these areas without any intentional seeding or cultivation. This may perhaps account for the fact that it does not require good drainage on cultivated land. Lands too poorly drained for the successful growing of alfalfa can be profitably planted to sweet clover.

Fall seeding is desirable in the coast and valley sections and early spring seeding in the northern counties and in the mountains. It is best to wait until the soil is thoroughly saturated and the winter rainy season established. Too early sowing may result in the germination of the seed by the first light rains. This followed by a protracted dry period may result in the loss of many seedlings and a subsequent poor stand.

The rate of seeding is from ten to twenty-five pounds per acre. T'en pounds per acre of good, clean, well-scarified, hulled seed are sufficient on a firm seed bed. Where unhulled seed is to be sown fifteen pounds per acre is desirable. Larger amounts of seed are necessary according to the quality of the seed and the condition of the seed bed. Shallow seeding, about one inch, is generally more successful than deep plantings. The roots grow rapidly during the cool winter season descending into the soil with a strong tap root which soon becomes more or less branched. The power of the roots to force their way into hard stiff soils is very great and herein lies one of its most beneficial features when grown on such soils. The roots are quite fleshy and when they decay at the end of the second season they leave humus channels which open up the soil and deposit large quantities of nitrogen.

The weight of the green roots from an acre of good sweet clover is estimated at twenty tons, so that even if the crop is cut for hay, large quantities of humus and nitrogen remain in the soil. The weight of the tops may be as high as thirty tons of green matter per 
acre. If this is plowed under as a green-manure crop rapid improvement in the texture and the humus content of the soil will take place.

The forage value of sweet clover is nearly equal to that of alfalfa. Much depends, however, on the character of the growth. If the plants have an abundance of space in which to grow the stems become too large and woody and are rejected by stock. For hay and green manure a thick stand of slender stemmed plants is the ideal.

The crop may be utilized as hay, pasture or soiling. Care should be taken not to set the mower too low as the buds for succeeding growths and for the second year are located on the lower branches. Too close pasturing by sheep may bring about a similar result, although hogs do little damage in this respect.

In order to get the best results from pasturing, the plants should be kept down below one foot in height. This will result in a succession of new tender palatable shoots being produced. Stock seldom bloat on sweet clover.

Mr. C. S. Frazier, in the Nebraska Farmer, gives in a concise way an experience which has been duplicated hundreds of times by others :

Last March the clover appeared, and by the second week of April the plants were eight inches tall with a dark-green color. Right at this time I had occasion to turn a herd of eattle onto that part of the farm to feed off a field of cornstalks. This sweet clover field was near the gate where the stock were turned into the field. To my surprise they never stopped to take a smell of the sweet clover at first. However, in a day or two I noticed three of the animals feeding on the clover, and in less than a week the whole herd was doing the same thing.

From that time on they stayed right on the clover until they had it eaten off close to the ground. I was somewhat concerned as to the safety of the clover and thereafter denied the cattle the right of grazing on that field. After the cattle were taken off, the sweet clover came on and made a heavy crop of seed. At no time during the past dry, hot season did it show any signs of being affected by the unfavorable weather.

From one to two or more cuttings of hay may be obtained each season. Where the growing season is a long one and irrigation possible, much larger yields may be obtained. A ton and a half to the acre per cutting may be expected.

On poor lands too much must not be expected of it the first season. Sweet clover will do much to bring back to life the unproductive wheat lands in California.

\section{BUR-CLOVER}

Bur-clover is well adapted to the coast and where not already abundant may be seattered on hill and pasture land in the autumn 
and scratched in lightly with a harrow or disk. It grows as a volunteer crop in grain fields, and makes a most valuable pasture for cattle, sheep and hogs.

\section{GRASSES}

The grasses that will respond if the seed is sown in the rainy season are: Italian rye-grass, English rye-grass, orchard grass, crested dog'stail grass, tall meadow oat-grass, red top and velvet grass.

In order to get the best returns a clean, well-prepared, firm seed bed should be made. Orchard grass prefers the shade, but the others will do well both in the open and in the shade. Tall meadow oat-grass is extremely drouth-resistant and will grow on poor soils, but the leafage at the base is meager. Red top does well in the seepage areas on the hillsides in the neighborhood of springs. Velvet grass delights in fog. Orchard grass, rye grasses, crested dog's-tail and velvet grass are especially adapted to sowing in the ashes of burnt-over redwood lands without treatment of the soil. The amount of seed to sow is about thirty pounds per acre for all except velvet grass, which takes ten, it being extremely light, weighing only seven pounds to the bushel.

\section{RYE}

The cereal rye may be sown in the fall on cultivated land and will provide good sheep and hog pasture by mid-winter.

\section{BARLEY}

Barley may be disked into irrigated alfalfa fields in the extreme southern counties and excellent sheep and hog pasturage provided by Christmas. The alfalfa does not seem to be injured in any way by this method of treatment.

The use of one or another of the above forage plants on the farm, together with a proper division of the range so as to permit each part to get a period of rest, will enable us to utilize California's winter rains and generally mild winter climate for an increased production of feed for stock. 


\section{REPORTS}

1897. Resistant Vines, their Selection, Adaptation, and Grafting. Appendix to Viticultural Report for 1896.

1902. Report of the Agricultural Experiment Station for 1898-1901.

1903. Report of the Agricultural Experiment Station for 1901-03.

1904. Twenty-second Report of the Agricultural Experiment Station for 1903-04.

1914. Report of the College of Agriculture and the Agricultural Experiment Station, July, 1913-June, 1914.

1915. Report of the College of Agriculture and the Agricultural Experiment Station, July. 1914-June, 1915

1916. Report of the College of Agriculture and the Agricultural Experiment Station, July, 1915-June, 1916.

1917. Report of the College of Agriculture and the Agricultural Experiment Station, July, 1916-June, 1917.

\section{BULLETINS}

No.

230. Enological Investigations.

241. Vine Pruning in California, Part I.

242. Humus in California Soils.

246. Vine Pruning in California, Part II.

248. The Economic Value of Pacific Coast Kelps.

249. Stock-Poisoning Plants of California.

250. The Loquat.

251. Utilization of the Nitrogen and Organic Matter in Septic and Imhoff Tank Sludges.

252. Deterioration of Lumber

253. Irrigation and Soil Conditions in the Sierra Nevada Foothills, California.

255. The Citricola Scale.

257. New Dosage Tables.

261. Melaxuma of the Walnut, "Juglans regia."

262. Citrus Diseases of Florida and Cuba Compared with Those of California.

263. Size Grade for Ripe Olives.

264. The Calibration of the Leakage Meter.

265. Cotton Rot of Lemons in California.

266. A Spotting of Citrus Fruits Due to the Action of Oil Liberated from the Rind.

267. Experiments with Stocks for Citrus.

68. Growing and Grafting Olive Seedlings

\section{CIRCULARS}

No.

113. Correspondence Courses in Agriculture.

114. Increasing the Duty of Water.

115. Grafting Vinifera Vineyards.

121. Some Things the Prospective Settler Should Know.

124. Alfalfa Silage for Fattening Steers.

126. Spraying for the Grape Leaf Hopper.

127. House Fumigation.

128. Insecticide Formulas.

129. The Control of Citrus Insects.

131. Spraying for Control of Walnut Aphis.

133. County Farm Adviser.

134. Control of Raisin Insects.

135. Official Tests of Dairy Cows.

136. Melilotus Indica.

137. Wood Decay in Orchard Trees

138. The Silo in California Agriculture.

138. The Generation of Hrdrocyanic Acid Gas in Fumigation by Portable Machines.

140. The Practical Application of Improved Methods of Fermentation in Californis Wineries during 1913 and 1914

141. Standard Insecticides and Fungicides versus Secret Preparations.

142. Practical and Inexpensive Poultry Appliances.

143. Control of Grasshoppers in Imperial Valley.

144. Oidium or Powderv Mildew of the Vine.

145. Suggestions to Poultrymen concerning Chicken Pox.

147. Tomato Growing in California.

148. "Lungworms."

150. Round Worms in Poultry.

151. Feeding and Management of Hogs.
No.

270. A Comparison of Annual Cropping, Biennial Cropping, and Green Manures on the Yield of Wheat.

271. Feeding Dairy Calves in California.

272. Commercial Fertilizers.

273. Preliminary Report on Kearney Vine. yard Experimental Drain.

274. The Common Honey Bee as an Agent in Prune Pollination.

275. The Cultivation of Belladonna in California.

276. The Pomegranate.

277. Sudan Grass.

278. Grain Sorghums.

279. Irrigation of Rice in California.

280. Irrigation of Alfalfa in the Sacramento Valley.

281. Control of the Pocket Gophers in California.

282. Trials with California Silage Crops for Dairy Cows.

283. The Olive Insects of California.

284. Irrigation of Alfalfa in Imperial Valley.

285. The Milch Goat in California.

286. Commercial Fertilizers.

287. Vinegar from Waste Fruits.
No.

152. Some Observations on the Bulk Handling of Grain in California.

153. Announcement of the California State Dairy Cow Competition, 1916-18.

154. Irrigation Practice in Growing Small Fruits in California.

155. Bovine Tuberculosis.

156. How to Operate an Incubator.

157. Control of the Pear Scab.

158. Home and Farm Canning.

160. Lettuce Growing in California.

161. Potatoes in California.

162. White Diarrhoea and Coccidiosis of Chicks.

164. Small Fruit Culture in California.

165. Fundamentals of Sugar Beet under California Conditions.

166. The County Farm Bureau.

167. Feeding Stuffs of Minor Importance.

168. Spraying for the Control of Wild Morning-Glory within the Fog Belt.

169. 1918 Grain Crop.

170. Fertilizing California Soils for the 1918 Crop.

171. The Fertilization of Citrus.

172. Wheat Culture.

173. The Construction of the Wood-Hoop Silo.

174. Farm Drainage Methods.

175. Progress Report on the Marketing and Distribution of Milk.

176. Hog Cholera Prevention and the Serum Treatment.

177. Frain Sorghum Seed.

178. The Packing of Apples in California. 